\title{
Nigeria as a Geo-Political Entity and Sovereign Actor in International Relations: Interrogating Its Emergence
}

\author{
Eze R. C. (Ph.D) \\ Department of Political Science, Nnamdi Azikiwe University, Awka, Anambra State, Nigeria \\ Email: ezeraphaelc@yahoo.com
}

\author{
Doi:10.5901/ajis.2016.v5n1p59
}

\section{Abstract}

\begin{abstract}
Utilizing the Secondary Sources of information gathering as well as Content Analysis, this paper x-rayed and questioned the metamorphosis of Nigeria as a single geo-political entity and sovereign participant in International Relations. It ascertains among others that the pre-colonial ethnic nationalities (such as the Igbo, Hausa/Fulani and Yoruba societies) lived in a variety of autonomous politico-economic systems, that the present day geo-political entity called 'Nigeria' is neither a 'Natural Evolution" nor a "willful or voluntary association" arrived at by the pre-colonial ethnic groups but an "artificial British colonial imposition or creation" culminating in the 1914 amalgamation of Northern and Southern protectorate; that even the nomenclature-'Nigeria' is of colonial origin; that with non-militant nationalism, Nigeria obtained her independence on October 1 , 1960 , but has, since then, at the standpoint of neo-colonialism, been participating peripherally in the relations among nations. The paper also proffers necessary panacea.
\end{abstract}

Keywords: Nigeria, Geo-political Entity, Sovereign Actor, Igbo, Hausa/Fulani and Yoruba.

\section{Introduction}

The objective of this work is to historically trace and examine the emergence of present Nigeria as a single geo-political entity as well as an independent actor in international relations with a view to proffering the necessary panacea for redirecting the country towards the road of progress, nationally and internationally. To this end, a critical inquiry into the condition prior to British colonialism shall be made. Therefore, a systematic exposition of the fate of the hitherto selfevolving autonomous pre-colonial societies during British colonial conquest, exploitation cum amalgamation of the Northern and Southern protectorates into a single geo-political entity in 1914 is also to be anatomized.

In the same vein, we shall analyze the nationalist activities that culminated in the achievement of independence on October 1, 1960, and hence, the emergence of Nigeria as a sovereign nation-state and actor in international relations. Summary and recommendations for building a better progressive political entity for Nigeria and a more effective participation in international relations were also provided. For our methodology, we adopted secondary sources of information gathering as well as Content Analysis due to the qualitative nature of our study.

This paper shall be of immense importance to students of History, Political science, Public administration and the general public who are pre-occupied with trends in the evolution of contemporary Nigeria as 'a single sovereign geopolitical entity'. Besides, it shall expose whether "Nigeria" as presently constituted is a product of "natural evolutionary development" or "an artificial foreign imposition".

The work shall also create awareness on whether (or not) the name 'Nigeria' as well as our skewed or "lopsided federalism" were also foreign imposition. Besides, the work shall help to ascertain the credibility or otherwise of the recently held "National Conference". Directly and indirectly, the research will go a long way towards fashioning a viable, stable, progressive, united (or peacefully separated) Nigeria that will engender rapid development and effective participation in international relations.

\section{The Pre-Colonial Epoch}

Contemporary Nigeria, the supposedly acclaimed giant of Africa, has historically developed from the pre-colonial epoch, through the colonial period, to the present post-colonial or neo-colonial era. Prior to the advent of the British imperialists, the various peoples of today Nigeria, lived in a variety of separate political systems with long and varied histories, norms and values and none called themselves "Nigeria". In this regard, Steve and K. Waltz (1971:281) noted inter-alia that: 
Nigeria did not exist as a distinct, identifiable entity before the gradual subjugation of its peoples by Great Britain in the late 19 th century.

Orewa G. O. (1998:1) recorded that "generally, about two hundred and fifty two separate nations (later referred by the colonial master as ethnic groups) existed". However, we have the Igbo, Hausa/Fulani and Yoruba as the three major ethnic groups.

\subsection{The lgbo}

In a nutshell, during the pre-colonial epoch, the Igbos lived in the eastern part of what is today called Nigeria. Contrary to European mystification of objective reality, they (the Igbos) had their own form of democratic government. There was diffusion of power rather than separation of powers. Thus, law-making, law implementation and law adjudication can be made at Umunna or kindred level (the primary political unit), the village assembly, as well as by the Age grades, UmuAda, Ozo title holders, Council of elders, the masquerades, Oracles and their priests etc. thus, due to the peculiar mode of their economy (communism), the Igbo society lacked centralized political authority.

P. N. Chikendu (2003:24) remarked that "in the Igbo pre-colonial society, authority was diffused and located at various points devoid of centralism and such fragmented pattern also showed egalitarianism, individualism, ad achievement motivation". It is a fallacy on the part of European bourgeois scholars to say that the Igbo political system is "acephalous" (headless). This is because, in line with democratic republicanism, meetings at either Umunna or at village assembly were always presided over on different occasions by and elected one, usually the most elderly. Besides, every adult has the right to air his view prior to the reaching of any final collective decision. This is why the Igbo pre-colonial government is variously referred to as republican, democratic and egalitarian in nature. Therefore, political pluralism rather than monism was the hallmark of the Igbo traditional political organization prior to the advent of the Europeans.

\subsection{The Hausa-Fulani}

Almost diametrically opposite that of the Igbo traditional system of government was the Hausa-Fulani. As Ibiyemi, $\mathrm{O}$. (1998) observed, the Hausa/Fulani operated a centralized administration based on the Emirate political system. In short, the Emir, who was under the Sultan of Sokoto was the spiritual (religious), political and administrative head of his Emirate. He was assisted in the administration of the emirate by a number of officers whom he appointed such as Waziri (Chief Adviser), Madawaki (Army Commander) Dogari (in charge of police), Maaji (responsible for the Treasury), etc.

The emirate was divided into districts, villages and wards-each with a head. The whole legislative processes were based on the Islamic religion through the Sharia or Quoranic laws. The Alkalis who were trained in interpretation and application of the Sharia laws presided over Alkali courts in the villages, districts and the capital city while the Emir was the overall head of the judiciary and presided over the court of appeal (on serious criminal cases and land disputes) in his palace. In reality, the Hausa/Fulani pre-colonial administration was feudalistic, monarchical and theocratic.

\subsection{The Yoruba}

In the pre-colonial era, Yoruba people inhabited he western part of our present Nigeria. In the pre-colonial structure of government, the Oba was the political, cultural and sometimes spiritual/religious head of his kingdom. Unlike the Hausa/Fulani Emir, the Oba was not an absolute ruler but had chiefs with whom the held consultations and both parties served as checks and balances on each other. The Oba with his chiefs exercised judicial powers especially over serious crimes, allocated land to people, settled land and other inter-ward disputes and saw to the general welfare of the people, (Ibiyemi O., 1998).

In the organization of the Yoruba kingdom, the council of chiefs or the "Oyomise" plays prominent role. The old Oyo Empire, the leader of the council of chiefs was the "Bashorun" who also acted as the Prime Minister of the kingdom. The council of chiefs (Oyomesi) was the kingmakers. They were not only empowered to elect a new king at the demise of one, but also to remove an Oba who violated the tradition of the community via "the parrot-egg gift which made the Oba commits suicide" (Chikendu, P. N. 2003:23). The chief as the Oba's advisers, met to discuss issues and take decisions, which they presented, to the Oba, who usually accepted such decision/advice (but was not bound to accept).

Another major political institution of the Yoruba kingdom was the 'Ogboni Fraternity'-a secret society that comprised prominent elders and headed by the 'Oluwo'. The fraternity checked the excesses of the kingmakers in the area of dethronement of an Oba and performed rituals on behalf of the kingdom. 
With the village, heads (Baale) and ward heads (Mogaji) appointed by the Oba, there was effective decentralization of administration. Various 'Age-grades' play roles such as security and general maintenance of law and order, environmental sanitation, civic duties like construction of roads, markets and public buildings as well as mass hunting, and organizing joint planting and harvesting. Generally, the Yoruba pre-colonial political system was semi-feudalistic, semi-monarchical and theocratic.

The foregoing analysis of our pre-colonial societies (The Igbo, Hausa/Fulani and Yoruba), therefore, buttresses the contention of J. E. Casely-Hayford (in Walter Rodney, 1982:40) that:

Before even the British came into relations with our people, we were a develop people, having our own institutions, having our own ideas of government.

The interactions between different pre-colonial communities were determined by the objective interests of the concerned parties and without any external forces (unlike today Nigeria) dictating the nature and direction of the domestic forces. The economic life of the pre-colonial societies was internally consistent, and above all, their system worked. Since the socio-political system was closely related to the economic infrastructure, both functioned in harmony.

Although the pre-colonial societies were separated from one another, none of the modes of production existed in pure form. Elements of one mode existed in the other. For instance, all of them possessed certain common features such as the extended family system as a welfare mechanism, land as the major means of production for relevant bio-social needs (rather than for the present expanded reproduction of private capital), and the use of relevant socio-cultural norms attuned to the demands of a self-centered economy. Therefore, the status-quo remained this day until capitalist Europe awakened from its own dark ages and began to look about for worlds to conquer for their selfish materialistic interest.

\section{Colonial Conquest, Amalgamation, Nationalism Cum Independence}

Karl Marx (n.d) asserted that in the $16^{\text {th }}$ and 17 the centuries, the revolution that took place in commerce with the geographical discoveries speeded up the development of merchant capital, and hence contributed one of the principal elements in furthering Western Europe's transition from feudal to capitalist mode of production. With the end of slave trade (due to the discovery of more cost-saving machines) and resort to trade on legitimate goods, the need for a constantly expanding market for its production led the Western bourgeoisie to scramble discover and colonize other parts of the world.

Thus, in 1861 there was the annexation of Lagos as British colony. By 1884, the 'scramble for Africa' by European capitalist powers, notably Britain, Portugal, France and Germany, was fast dive-nosing from the level of co-operation, to that of competition, conflict and near-warfare. Chinweizu (1978) averred that: to arrest the situation, the European competing powers succeeded in signing the Berlin Treaty after the 1884-1885 conference. Here, the European powers recognized that British influence was paramount in the Niger Delta area due to the trading activities of the 'Royal Charter Company' along the River Niger.

1886, Britain granted a 'Royal Charter' to the Royal Niger Company and gave it political authority in the areas it controlled. By 1990, the charter was revoked and the trading territories were taken over by the British authority. Consequent upon the rapid expansion (by forced protection treaties and outright conquests) by British authority, there was the establishment of three separate territories: the Colony of Lagos, the Protectorate of Northern Nigeria and the Protectorate of Southern Nigeria. Lord Fredrick Lugard was appointed the High Commissioner for the Northern Protectorate where he introduced the British colonial administration policy of "Indirect rule".

Through this policy, the colonial administration sought to ensure the maximum exploitation of the country's resources for the interest of Britain (and her Western allies) through the intermediary services of the traditional rulers.

In 1906, Lagos colony and the Southern Protectorate, were united and called the "Colony and Protectorate of Southern Nigeria". In 1914, the Southern and Northern protectorates, were amalgamated and called "the Colony and Protectorate were amalgamated and called "the Colony and protectorate of Nigeria". This therefore witnessed the final emergence of Nigeria as a "single geo-political entity" (even though still under British colonialism). Concerning the origin and choice of the territorial name, (Nigeria), Guy Arnold (1977:ix) stated that the name -Nigeria- "was coined in 1897 (from Niger area) by Flora Shaw- the wife of Lord Lugard in an article in The Times of London, and it stuck".

On the geographical location of Nigeria, Sir Alan Burns (1972) noted that Nigeria is situated on the west coast of Africa, on the shores of the Gulf of Guinea (which included the Bights of Benin and Biafra). It lies between the parallels of $4^{\circ}$ and $14^{\circ}$ north and is thus entirely within the tropics. It is bounded on the south by the sea, on the west and north by the Republic of Dahomey (now Benin) and the Niger Republic and on the east by the former German Colony of Kamerun, 
now the Republic of Cameroon. Sir Alan Burns (1972:18) noted further that:

The approximate area of Nigeria is 356, 669 square miles, more than four times the size of the Great Britain. The population is estimated to be greater ...than that of Australia, Canada and New Zealand combined, and much greater than that of any other state in Africa.

On the other hand Ray Ofoegbu (1977) remarked that between 1913 and 1960, the colonial office in London (the office of the last resort) was represented in Nigeria by different British colonial governors. Thus, we have, Sir (Lord) Fredrick Lugard (1913-1930), Sir Donald Cameron (1931-1935), Sir Bernard Bourdillon (1935-1943), Sir Arthur Richards (1944-1947), Sir John Macpherson (1948-1955), Sir James Robertson (1955-1960).

During this colonial epoch, the indigenous political economy was abruptly halted, nay re-structured and peripherally integrated into the western capitalist economy via Britain as a mere raw material producing appendage. Worthy to note too is that in this colonial epoch, the Richards Constitution of 1946, Macpherson constitution of 1951 and the Lyttleton Constitution of 1954, among others, enthroned unequal regionalism, quasi-federalism and full federalism respectively.

The socio-economic and political relationship between the colonialist (Britain) and he colonized (Nigeria) was far from symbiotic. This is because of the parasitic, subjugatory and exploitative tendencies of colonialism. In order to liberate themselves from he shackles of colonialism, the dehumanized Nigerians embarked on nationalism. This connotes the totality of all the efforts and activities directed by Nigerians (especially the alienated educated elites like Dr. Nnamdi Azikiwe, Chief Obafemi Awolowo, etc) for the achievement of self-rule or independence. In this regard, Guy Arnold (1977: ix) noted inter-alia that:

Nationalist agitation began to grow in the 1930s and was given a tremendous boost by the event of the Second World War. From the mid 1940s onwards a series of constitutions and politics surrounding their attainment took steps toward self-government and then independence and this process dominated the last fifteen years of British rule.

Chinweizu has noted the inter-play of three conflicting forces in the process of the nationalist struggle. Said he: "The confrontation between European imperialism and African anti-colonialism thus became a three concerned affray between traditional rulers; the rising petite bourgeois and the European rulers" (Chinweizu, 1978: 88). In a related sense, Almond and Coleman noted that the nationalist movement faced obvious difficulties because it had to be directed first against indigenous mentors of he colonialists (the traditional rulers) and then against imperialism. Jones Quartey (1965) wrote that Azikiwe had decided that the traditional leaders of Africa had outlived their usefulness to their communities and that hey must either be reformed or removed, adding that the traditional leaders and their way s of life constitute old Africa which must be destroyed.

In reply to Azikiwe's contention, (Jones Quartey, 1965:124) remarked that one of the leaders of the so-called Old Africa-Nana Ofori Atta complained that:

If the youths of the country are to be taught and educated to disrespect and to show open contempt to their chiefs and elders and leading public figures with whose views or with whose person those teachers are not in agreement, or for whom they have animosity, then there is a real danger.

From Lord Lugard's colonial governorship (1913-1919) to Sir James Robertson's (1955-1960), the nationalists directed their efforts (peacefully) against colonialism and the various colonial constitutions. On the non-militant modus operandi of Nigeria's road to independence, Femi Omasanya (1984:5) observed that:

Nigeria independence had been achieved through patient negotiation between Nigerian urban and petit bourgeois nationalist and their colonial masters. This was unlike the situation in China, Algeria, Angola, Mozambique and even Zimbabwe. While Nigerian negotiators for independence were busy drinking tea, signing documents and shaking hands in Her Majesty's London, their revolutionary counterpart were on the battle field.

Similarly, Ray Ofoegbu (1980) noted that Nigeria's process of becoming independent was not through revolutionary strategy and that independence was achieved on a platter of gold. He added, "This ensured the continuation of pro-British and pro-Western external policy behaviour after independence" (Ray Ofoegbu, 1980:155). And so, on October 1, 1960, Nigeria got her independence from Great Britain with retention of the socio-economic and political structures bequeathed by the colonial overlords. Thus, while 1914 marked Nigeria's emergence as a 'single geopolitical entity', 1960 witnessed her acquisition of 'sovereignty', and hence, a de jure independent actor in international relations. 
Unfortunately, however, from Prime Minister Belewa to President GoodLuck, our 'independence' remains 'dependence', and underdevelopment coupled with incessant ethno-religious cum political instability and as Kwame Nkrumah, in Daniel A. Offiong (1980:122) aptly noted:

A state in the grip of neo-colonialism is not a master of its own destiny.

\section{Conclusion}

In this work, we ascertained that the hitherto separate and autonomous societies that make up today Nigeria were at different stage of natural autonomous socio-economic cum political development before the British imperialists forcefully intervened. Through deceptive treaties and outright military conquests, the various nationalities (such as the Igbo, Yoruba, Hausa/Fulani, etc) were coerced into protectorates, horribly subjugated, mercilessly exploited and later in 1914 had the Northern and Southern Protectorate finally amalgamated into a single geo-political entity which till date is called Nigeria. Thus, the Nigeria union is in deed a 'foreign imposition' rather than a willfully or voluntarily decided polity on the part of the indigenous populace.

We also discovered that even the nomenclature-'Nigeria' was also a British colonial imposition. So also was our lopsided Federalism. It was also ascertained that our pre-colonial self-evolving indigenous socio-economic and political structures were disassembled by the British imperialists and peripherally integrated into the orbit of Western capitalist system. After independence on October 1, 1960 (via non-militant or peaceful nationalism), our post-colonial civilian and military rulers retained the 1914 British amalgamation and maintained into-to a neo-colonial status quo. This has resulted in Nigeria's adverse dependency syndrome in international relations, continued national under-development, incessant ethno-religious cum political crisis such as the Biafra (Igbo) secession, continuation of Movement for the actualization of the Sovereign State of Biafra; the Movement for the Emancipation of Niger Delta; the devastating Boko Haram Terrorists quest for Islamization of Nigeria, etc. The escalating national disunity (and more) must have informed the United States' Central Intelligence Agency (CIA) report that Nigeria might disintegrate by 2015.

Indeed, the 1914 colonial amalgamation of the incompatible Northern and Southern Nigerians - into a single geopolitical entity has done more harm than good to Neo-colonial Nigeria-nationally and internationally. Rather than retaining forced marriage of 'strange bed-fellows' with the attendant in-house fatalistic fighting detrimental to any meaningful development, realistic panacea requires total 'divorce' or at least 'peaceful separation' of the couples. Referendum is therefore urgently needed for each of the major ethnic groups in Nigeria. Cosmetic or symptomatic therapy like President Jonathan's recently organized 'National Conference' (which its outcome may hardly be fully implemented by benefactors of the status quo) is mere palliative measure rather than 'causative' therapy especially with its 'no-go-area' over discourse on need (or otherwise) for amicable 'separation' or secession by interested ethnic groups. Democracy entails 'Freedom of Association', and hence 'Referendum' which enables any ethnic group to choose either to remain or opt out of the Nigerian state and pursue her own destiny (including religion) at her own pace (nationally and internationally). However, incumbent political office holders and economic benefactors of 'one Nigeria' and their 'Divide-and-Rule' foreign collaborators would always resist such referendum via propaganda of the advantages of large population, landmass and the likes without remembering the viability of small Israel, Britain, France, Switzerland, etc. After over one hundred (19142015) years of one Nigeria, Nigeria remains a third world country and amputated giant of Africa characterized by monumental corruption and incessant ethno-religious cum political crisis. Nigerians should learn from the fifteen republics of the defunct Soviet Union, former components of Yugoslavia, North and South Sudan, etc, that now carry their destiny in their own hands devoid of forced marriage or imposed single geo-political entity.

In conclusion therefore, the candid recommendation of the researcher is that the presidency should courageously and selflessly conduct 'Referendum' for (at least) each of the major ethnic groups (Igbo, Hausa/Fulani and Yoruba) in Nigeria to 'willingly' decide to either remain in the Nigeria state or opt out and form independent polity, separately coexisting and carrying out her internal and international relations. In the end, the various ethnic groups may voluntarily choose to remain under the present Federal Republic of Nigeria. On the other hand, they may amicably go their ways and probably (along ethnic lines) form Republic of Biafra, Arewa Republic, Odua Republic or the likes which will no doubt highly reduce if not totally eradicate (in the new independent polities) the hitherto endemic ethno-religious conflicts, adverse inter-ethnic raw struggle to control power at the central government and imperialistic inter-ethnic foreign manipulations jeopardizing national unity and development as well as effective participation in international relations. 


\section{References}

Alan Burns, (1972). History of Nigeria, London: George Allen Unwin Ltd.

Chinweizu, (1978). The West and the Rest of Us, London: NOK Publishers.

Daniel, A. Offiong (1980). Imperialism and Dependence, Enugu: Fourth Publishing Company Ltd.

Femi Omasanya, (1984). "Nigeria in Leadership Crisis" Satellite, January 6.

Guy Arnold, (1977). Modern Nigeria, London: Longman Group Ltd.

Ibiyemi O. et al, (1998). Round-up Government, Nigeria: Longman Nig. Plc.

J. E. Casely Hayford, (1982). In Walter Rodney, How Europe Underdeveloped Africa, Enugu: Ikenga Publishers.

Jones Quartey, (1965). A Life of Azikiwe, Baltimore: Penguin Books.

Karl Marx, (n.dp). Capital, Vol. III, Chapter XX.

Orewa G. O, (1998). We are all Guilty: The Nigeria Crisis, Ibadan: Spectrum Books Ltd.

P. N. Chikendu, (2003). Nigerian Politics and Government, Second Edition, Enugu: Academic Publishing Co.

Ray Ofoeggbu, (1977). Government for the Certificate Year, London: George Allen and Unwin.

Steve and K. Waltz, (1971). Conflict in World Politics, Massachusetts: Winthrop Publishers. 